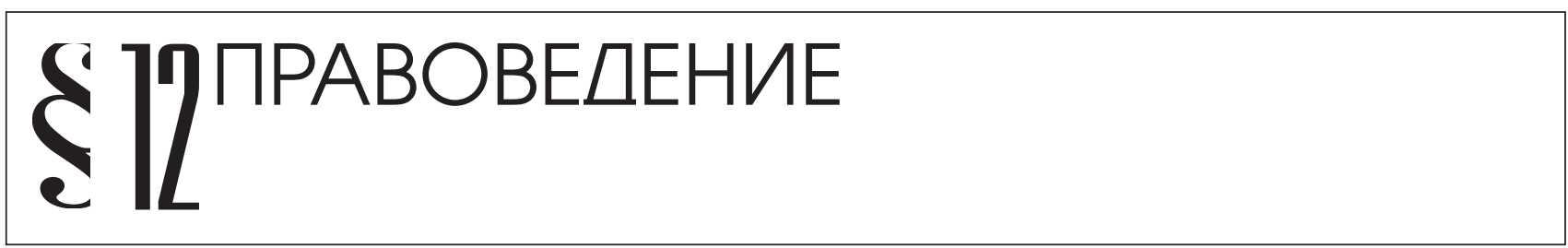

Загвоздкин Н.H.

\title{
ЛИЧНЫЙ ОБЫСК И СХОЖИЕ ПРАВОВЫЕ ПОНЯТИЯ: ПРОБЛЕМЫ РАЗГРАНИЧЕНИЯ
}

\begin{abstract}
Аннотация: Предметом исследования являются теоретические, законодательные и практические аспекты личного обыска и сходных с ним правовых прочедур, таких как личный досмотр, личный осмотр, наружный досмотр и другие. Цели статьи: 1) выявить коллизии норм административного, уголовно-процессуального, оперативно-розыскного, уголовно-исполнительного и иного законодательства, регламентирующих принудительное обследование физического лица и изъятие у него чего-либо; 2) обозначить проблемы следственной и судебной практики применения указанных норм; 3) предложить возможные пути их решения. Методологической основой исследования является диалектический метод познания. Методы исследования: сравнительно-правовой, историко-правовой, логико-юридический, системно-структурный. Новизна полученных результатов заключается в межотраслевом и междисииллинарном подходе к анализу сходных $c$ личным обыском действий. Выводы сформулированы в виде предложений: 1) отказаться от множественности используемых в нормативно-правовых актах понятий, означающих принудительное обследование физических лии; 2) усовершенствовать процедуры такого обследования применительно к разным отраслям федерального законодательства.
\end{abstract}

Ключевые слова: Коллизия норм, личный обыск, личный досмотр, личный осмотр, наружный досмотр, наружный осмотр, оперативно-розыскное мероприятие, предварительная проверка, процедура, следственное действие. Abstract: The subject of this research is the theoretical, legislative, and practical aspects of personal search and similar legal procedures, such as frisk, pat down, external frisk, and others. The goals of the article are: 1) to determine the collisions of norms of administrative, criminal procedural, investigative, criminal law enforcement, and other legislation that regulates forced search of a person and confiscation of something from an individual; 2) to mark the issues in investigative and judicial practice of application of such norms; 3) to propose possible solutions. The novelty of the results acquired consists in the inter-industry and interdisciplinary approach towards the analysis of acts similar to personal search. The conclusions are formulated as the following propositions: 1) to remove the multiplicity used within the normative-legal acts of notions that pertain to forced search of individuals; 2) to improve the procedures of such search within various branches of the federal legislation.

Keywords: Preliminary check, detection, examination, external frisk, pat down, frisk, personal search, conflict of norms, procedure, investigation.

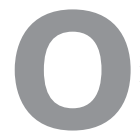

бращение к обозначенной теме вызвано многочисленными коллизиями норм разных отраслей отечественного законодательства (административного, уголовно-процессуального, оперативно-розыскного, полицейского, уголовно-исполнительного и иного), регламентирующих принудительное обследование физического лица (его тела, одежды, личных вещей) и изъятие у него чего-либо до и после начала уголовного судопроизводства (возбуждения уголовного дела).

В. М. Корнуков и Р. Ш. Валиев в фундаментальном исследовании, посвященном личному обыску, обоснованно указывают, что его правовая природа сложна и неоднозначна, а практика применения противоречива, непоследовательна и не всегда законна. Зачастую личный обыск проводится под прикрытием других процессуальных действий (осмотр места происшествия, осмотр помещения, освидетельствование) либо мер административно-правового характера (личный досмотр, досмотр вещей). При этом грубо нарушаются права обыскиваемых лиц, а доказательственное значение полученных результатов вызывает серьезные сомнения. Личный обыск как весьма специфическое и своеобразное следственное действие 
DOI: $10.7256 / 1811-9018.2015 .8 .15966$

При цитировании этой статьи сноска на доі обязательна

\section{Право и политика 8 (188) $\bullet 2015$}

обладает довольно широкими доказательственными возможностями, с помощью которого устанавливаются событие преступления, виновность лица, мотивы преступления и другие значимые для уголовного дела обстоятельства. Чаще всего обыскиваются лица, подозреваемые в незаконном обороте наркотических средств, оружия, в совершении преступлений против собственности - в связи с непосредственным обнаружением орудия преступления или предметов преступного посягательства [36].

С правовой природой личного обыска связан вопрос о возможности его производства до возбуждения уголовного дела. Необходимость личного обыска возникает в момент физического захвата предполагаемого преступника. Учитывая, что уголовное дело еще не возбуждено, практические работники в подавляющем большинстве случаев оформляют фактически проведенный личный обыск задержанного протоколами осмотра места происшествия либо личного досмотра.

Без личного обыска невозможно пресечь, предупредить или раскрыть преступление. В США, Англии и других странах законодательно закреплено и активно используется полицией правило «останови и обыщи». Уголовно-процессуальное законодательство Украины предусматривает возможность личного обыска без вынесения специального постановления при физическом захвате подозреваемого [36].

Комментируя приведенные В. М. Корнуковым и Р. Ш. Валиевым примеры из зарубежного законодательства, отметим отсутствие в нем понятия «возбуждение уголовного дела», являющегося неотъемлемым атрибутом Уголовно-процессуального кодекса Российской Федерации [3] (далее по тексту - УПК) и стадией отечественного уголовного судопроизводства.

Подмену личного обыска личным досмотром авторы считают симптоматичным, так как зачастую выявление оснований для возбуждения уголовного дела невозможно без проведения обследования человека, его одежды и находящихся при нем вещей. Личный обыск в уголовном судопроизводстве не должен подменяться аналогами из других отраслей права и, как предлагают авторы, в порядке исключения должен быть разрешен до возбуждения уголовного дела [36].

К сожалению, В. М. Корнуков и Р. Ш. Валиев, рассматривая в отдельном параграфе своей работы отличие личного обыска от других следственных действий и административного досмотра, оставили за рамками исследования ряд других нормативно-закрепленных понятий, применяемых в правоохранительной практике.
Назовем и охарактеризуем их последовательно.

1. Наружный осмотр одежды и вещей первоначально был предусмотрен Уставом патрульно-постовой службы милиции общественной безопасности РФ [18] (далее по тексту - Устав, ППС) применительно к задержанию и доставлению лиц, подозреваемых в совершении преступлений. Полагаем, что имелся в виду так называемый «физический захват» преступника до возбуждения уголовного дела (п. 15 ст. 5 действующего УПК), а не подозреваемого в процессуальном смысле этого понятия.

В пункте 148 Устава было записано, что в зависимости от обстоятельств наружный осмотр одежды и вещей, находящихся у задержанных, производится немедленно или в более удобный момент, когда можно получить помощь от других сотрудников милиции или граждан. Обнаруженное оружие и другие предметы, которые могут быть использованы для оказания сопротивления, нападения на наряд или побега, немедленно изымаются.

Видимо, исходя из того, что задержание правонарушителя (в том числе предполагаемого преступника) сотрудниками так называемых наружных служб органов внутренних дел (далее по тексту - ОВД) зачастую носит неожиданный характер, возможно в ситуации «один на один» (в том числе мужчина против женщины и наоборот), разработчики Устава не предусмотрели подробной процедуры наружного осмотра и правил оформления изъятия. Очевидно, что помощь других сотрудников и граждан, а тем более привлечение понятых в подобных ситуациях (ночное время, безлюдное место и др.) не только не всегда возможны, но и неуместны в силу реальной угрозы жизни и здоровью граждан. В соответствии с действующим законодательством и сложившейся практикой, обстоятельства физического захвата преступника должны быть документально отражены в подробном рапорте сотрудника ОВД, а после возбуждения уголовного дела - в протоколе его допроса в качестве свидетеля.

2. Наружный досмотр появился с принятием Устава ППС полиции [19], в пункте 266 которого произошла замена понятий. При этом словесное описание указанных действий (наружного осмотра и наружного досмотра) в действующем и утратившем силу Уставах полностью совпадает.

По мнению исследователей полицейского законодательства Г. И. Калмыкова, Н. Ю. Колчевской и А. П. Беликова, наружный досмотр отличается от административного досмотра, предусмотренного ст. 27.7 Кодекса РФ об административных правона- 
рушениях [4] (далее по тексту - КоАП) отсутствием понятых, возможностью проведения полицейским любого пола. При этом осуществляется визуальный осмотр верхней, иной видимой одежды доставляемого и видимых участков тела, похлопывание кистями рук по одежде и вещам доставляемого с целью обнаружения и изъятия оружия и других предметов, используемых для оказания сопротивления, нападения или побега. Основное предназначение наружного досмотра - обеспечение личной безопасности полицейского при доставлении лица к месту составления протокола об административной правонарушении [33, с. 9].

Учитывая зыбкую грань между административным и уголовным законодательством и правоприменительную практику, полагаем, что речь следует вести не только об административном правонарушителе, но и о преступнике.

С практической точки зрения пренебрежение наружным досмотром задержанного правонарушителя зачастую приводит к гибели или ранениям сотрудников полиции, что подтверждается многочисленными примерами из средств массовой информации $[34,35]$.

Здесь, на наш взгляд, необходимо обратить внимание на три аспекта служебно-боевой подготовки. Во-первых, Устав ППС написан для полицейских с минимальным уровнем правовых знаний. Во-вторых, не только они, но и офицеры с высшим юридическим образованием зачастую не отличают личный досмотр от наружного, упомянутого в единственном пункте Устава. В-третьих, с формальной точки зрения участковые и оперативные уполномоченные полиции, попадая в сходные с сотрудниками ППС ситуации задержания правонарушителей, не имеют права наружного досмотра. Таким образом, отсутствие единообразия в терминологии ведомственных документов, на наш взгляд, порождает проблемы в методическом обеспечении служебно-боевой подготовки сотрудников ОВД.

Так как наружный досмотр (как и ранее - наружный осмотр), к сожалению, предусмотрен (точнее единожды упомянут) лишь в ведомственном подзаконном нормативном акте (приказ МВД России), на наш взгляд, предпочтительнее использовать возможности такого действия как личный досмотр, - учитывая его более подробную регламентацию в федеральном законодательстве.

3. Личный осмотр как новое правовое понятие впервые появился в Федеральном законе «О полиции» [13] (далее по тексту - Ф3 «О полиции») и для некоторых исследователей (не говоря уже о сотрудниках полиции), к сожалению, остался незамеченным.
Так, Г. И. Калмыков, Н. Ю. Колчевская и А. П. Беликов утверждают, что в практической деятельности сотрудников ОВД по обеспечению общественного порядка и безопасности при проведении массовых мероприятий используется понятие «оперативного досмотра» больших групп лиц с использованием технических средств с целью выявления холодного и огнестрельного оружия, а также предметов типа металлических прутьев, палок и других. Авторы утверждают, что порядок и основания оперативного досмотра законодательно не регламентированы [33, с. 8].

Однако вышеописанный «оперативный досмотр» - это и есть личный осмотр граждан и находящихся при них вещей, который осуществляется полицией совместно с организаторами публичных и массовых мероприятий в целях обеспечения безопасности граждан и общественного порядка при проходе на территории сооружений, на участки местности либо в общественные места. При отказе граждан подвергнуться личному досмотру они не допускаются на публичные и массовые мероприятия (пункт 18 части 1 ст. 13 Ф3 «О полиции»).

Таким образом, личный осмотр, основания и порядок его проведения законодательно регламентированы, но в самом общем виде, то есть предельно кратко, что заведомо порождает проблемы в правоприменении. Необходимость рассматриваемой новеллы вызывает у нас обоснованные сомнения, так как личный осмотр по своей правовой природе и по существу - разновидность личного досмотра, похожего на предполетный досмотр пассажира воздушного судна, предусмотренного ст. 85 Воздушного кодекса РФ [2] (далее по тексту - ВК РФ). Объединяет их (личный осмотр и предполетный досмотр), во-первых, то, что гражданин вправе отказаться от прохождения этих процедур. Во-вторых, отсутствует ясность относительно документального оформления указанных действий.

Выстраивая иерархию правовых понятий, регламентирующих принудительное обследование физического лица (его тела, одежды и личных вещей), после наружного осмотра (утратившего силу), наружного досмотра и личного осмотра следует назвать личный досмотр - разновидность досмотра как меры обеспечения производства по делу об административном правонарушении (п. 3 ч. 1 ст. 27.1 КоАП). Личный досмотр, досмотр вещей, находящихся при физическом лице, осуществляется в случае необходимости в целях обнаружения орудий совершения либо предметов административного правонарушения. 


\section{Право и политика 8 (188) • 2015}

Досмотр производится должностными лицами, указанными в ст.ст. 27.2, 27.3 КоАП, то есть теми, кто вправе осуществлять доставление и административное задержание - должностными лицами ОВД (полиции), внутренних войск, пограничных органов и др. Полный перечень должностных лиц системы МВД России, уполномоченных осуществлять административное задержание, приведен в особом приказе МВД России [20].

Личный досмотр производится лицом одного пола с досматриваемым в присутствии двух понятых того же пола. Законодательная регламентация института понятых вызывает обоснованную критику. Участие граждан в качестве незаинтересованных наблюдателей сформулировано как право, а не обязанность. Отказ гражданина в ответ на просьбу (приглашение) быть понятым не влечет за собой никакой правовой ответственности. Блюстители правопорядка постоянно сталкиваются с нежеланием граждан в этом статусе содействовать борьбе с правонарушениями [29].

В уголовно-процессуальном и административном законодательстве произошли серьезные позитивные изменения, связанные с кардинальным сокращением института понятых $[15,17]$, однако обязательное их участие в личном обыске и в личном досмотре сохранено. Учитывая распространенность в России таких действий правонарушителей в отношении сотрудников правоохранительных органов как злостное неповиновение, сопротивление, вооруженное нападение, не следует забывать о реальной угрозе для жизни и здоровья граждан, привлекаемых к участию в различных правовых процедурах.

В исключительных случаях при наличии достаточных оснований полагать, что при физическом лице находится оружие или иные предметы, которые могут быть использованы для причинения вреда жизни и здоровью других лиц, личный досмотр, досмотр вещей, находящихся при физическом лице, могут быть осуществлены без понятых (ч. 4 ст. 27.7 КоАП).

О досмотре составляется протокол либо делается соответствующая запись в протоколе о доставлении или в протоколе об административном задержании. В протоколе делается запись о применении фотосъемки, видеозаписи, иных установленных способов фиксации вещественных доказательств, материалы которых прилагаются к протоколу (ч.ч. 6-7 ст. 27.7 КоАП).

Нормой зарубежной полицейской практики становится применение видеорегистраторов, в том числе закрепляемых на одежде, фиксирующих в режиме он-лайн видео- и аудиоинформацию о служебной деятельности. Такой опыт заслуживает пристального внимания и широкого распространения в России, так как позволяет объективно оценить правомерность действий полицейских.

Зачастую исследователи личного досмотра ограничиваются анализом норм КоАП, не обращая внимания на иные нормативно-правовые акты, подготовленные другими разработчиками, принимавшиеся в разное время, применительно к разным особенностям регулируемых общественных отношений, что неизбежно вызывает коллизии.

Личный досмотр предусмотрен в ст. 13 Ф3 «О полиции» (ранее - в ст. 11 Закона РФ «О милиции» [7]), в ст. 30 Закона РФ «О Государственной границе РФ» [8], в ст. 85 Воздушного кодекса РФ, в ст. 48 ФЗ «О наркотических средствах и психотропных веществах» [11], в ст.ст. 12 и 31 Федерального конституционного закона (далее - ФКЗ) «О чрезвычайном положении» [6], в ст. 11 Ф3 «О противодействии терроризму» [12], в ст. 117 Таможенного кодекса Таможенного союза [5] (далее - ТК ТС) и в некоторых других законах.

Проанализируем особенности этих разновидностей личного досмотра с учетом хронологии принятия законов, их регламентирующих.

Так, в пункте 2 части 1 ст. 11 Закона РФ «О милиции» было закреплено право милиции при наличии достаточных данных о том, что граждане имеют при себе оружие, боеприпасы, взрывчатые вещества, взрывные устройства, наркотические средства или психотропные вещества, производить в порядке, установленном федеральным законом, личный досмотр лиц, досмотр их вещей, ручной клади и багажа, изымать указанные предметы, средства и вещества при отсутствии данных о наличии законных оснований для их ношения или хранения.

В пункте 3 части 2 ст. 30 Закона РФ «О Государственной границе РФ» закреплено право пограничных нарядов задерживать и досматривать лиц, в отношении которых имеются основания подозревать их в нарушении пограничного режима. Представляет интерес сама возможность участия в досмотре понятых - с учетом специфики автономной деятельности пограничных органов ФСБ вдали от населенных пунктов, в пограничной зоне, где в силу режимных запретов не предполагается присутствие посторонних лиц.

В части 1 ст. 85 ВК РФ закреплено, что в целях обеспечения безопасности пассажиров и членов экипажа воздушного судна обязательному предполетному досмотру, а также послеполетному досмотру подлежат воздушное судно, его бортовые запасы, члены экипа- 
жа, пассажиры, багаж, в том числе вещи, находящиеся при пассажирах, а также грузы и почта. Далее записано, что проведение предполетного и послеполетного досмотров не исключают возможность проведения досмотра при осуществлении оперативно-розыскной, уголовно-процессуальной и иной деятельности уполномоченными на то лицами в порядке, установленном законодательством РФ (ч. 2 ст. 85 ВК РФ).

Комментируя приведенные нормы, отметим, что с формально-юридической точки зрения в оперативно-розыскной и уголовно-процессуальной деятельности досмотр не возможен, так как не предусмотрен соответствующим законодательством. Налицо очередная коллизия норм разных кодексов и федеральных законов.

При отказе пассажира от предполетного досмотра договор воздушной перевозки пассажира считается расторгнутым (ч. 3 ст. 85 ВК РФ). В этой норме усматриваются аналогии с процедурой личного осмотра (п. 18 ч. 1 ст. 13 Ф3 «О полиции»), отказ от которой влечет невозможность прохода лица на публичные и массовые мероприятия.

В части 3 ст. 48 Ф3 «О наркотических средствах и психотропных веществах» закреплено право должностных лиц ОВД, госнаркоконтроля, таможенных органов, органов ФСБ производить досмотр граждан, почтовых и багажных отправлений, транспортных средств и перевозимых грузов при наличии достаточных оснований полагать, что осуществляется незаконный оборот наркотических средств, психотропных веществ и их прекурсоров.

В пункте «г» части 1 ст. 12 ФКЗ «О чрезвычайном положении» в качестве мер и временных ограничений предусмотрены личный досмотр, досмотр вещей, жилища и транспортных средств, а часть 1 ст. 31 разрешает личный досмотр задержанных за нарушение правил комендантского часа. Отметим, что досмотр жилища уникален, так как другими законами не предусмотрен.

В пункте 12 части 3 ст. 11 Ф3 «О противодействии терроризму» предусмотрено при проходе (проезде) на территорию, в пределах которой введен правовой режим контртеррористической операции, проведение досмотра физических лиц и находящихся при них вещей, а также досмотра транспортных средств и провозимых на них вещей, в том числе с применением технических средств.

В статье 117 ТК ТС процедура личного таможенного досмотра описана более детально, чем в КоАП. Должностное лицо обязано объявить решение о проведении досмотра, ознакомить досматриваемого с его правами и обязанностями и предложить добровольно выдать скрываемые товары. Помещение для досмотра должно быть изолированным, отвечать санитарно-гигиеническим требованиям и исключать доступ других физических лиц. Обследование тела должно проводиться только медицинским работником с использованием при необходимости специальной медицинской техники.

К сожалению, в отличие от таможенников, у сотрудников ОВД в силу специфики служебной деятельности зачастую нет возможности проведения личного досмотра в специально оборудованном помещении.

В пункте 16 части 1 ст. 13 Ф3 «О полиции» закреплено право сотрудников полиции осуществлять в порядке, установленном законодательством об административных правонарушениях, личный досмотр граждан, досмотр находящихся при них вещей, а также досмотр их транспортных средств при наличии данных о том, что эти граждане имеют при себе оружие, боеприпасы, патроны к оружию, взрывчатые вещества, взрывные устройства, наркотические средства, психотропные вещества или их прекурсоры либо ядовитые или радиоактивные вещества, изымать указанные предметы, средства и вещества при отсутствии законных оснований для их ношения или хранения; принимать участие в досмотре пассажиров, их ручной клади и багажа на железнодорожном, водном или воздушном транспорте.

По мнению Г. И. Калмыкова, Н. Ю. Колчевской и А. П. Беликова, личный досмотр по своему правовому характеру отличается от личного обыска следующим: 1) сотрудник полиции не обязан предлагать гражданину добровольно выдать подлежащие изъятию предметы и документы (ч. 5 ст. 182 УПК); 2) процедура досмотра менее «строгая»; 3) досмотр проводится без судебного решения [33, с. 11-12].

Зная особенности разных видов досмотра, отметим, что личный таможенный досмотр предусматривает возможность добровольной выдачи (п. 2 ст. 117 TK TC).

В отличие от Закона РФ «О милиции» личный досмотр в ФЗ «О полиции» жестко увязан именно с административным, а не с федеральным законодательством. С формально-юридической точки зрения досмотр применим только к отношениям, регулируемым административным законодательством. Сходную позицию занимает Конституционный Суд РФ, разграничивая в постановлении от 2 июля 1997 г. № 11-П административное и уголовно-процессуальное задержание: «Административное за- 


\section{Право и политика 8 (188) 2015}

держание как мера обеспечения производства по делам об административных правонарушениях не может применяться в делах об уголовных правонарушениях. В противном случае были бы нарушены принципы как уголовного (уголовно-процессуального), так и административного (административнопроцессуального) законодательства» [22].

Комментируя приведенный тезис, согласимся, что подмена уголовно-процессуальных процедур административными недопустима. Однако нельзя не видеть генетические взаимосвязи административного, оперативно-розыскного, уголовного и уголовно-процессуального законодательства, которые проявляются в неразрывной связи соответствующих видов правоохранительной деятельности, в смене одного вида другим. Административные доставление, досмотр и задержание правонарушителя зачастую способствуют выявлению признаков преступлений и, предшествуя уголовному судопроизводству, влекут за собой возбуждение уголовного дела, задержание подозреваемого, его личный обыск и т. д. В отличие от КоАП, другие кодексы и законы, как следует из вышеизложенного, прямо предусматривают возможность выявления с помощью досмотра достаточных данных, указывающих на признаки преступления, что является основанием для возбуждения уголовного дела (ч. 1 ст. 140 УПК).

Личный обыск подозреваемого, обвиняемого производится в целях обнаружения и изъятия предметов и документов, могущих иметь значение для уголовного дела (ч. 1 ст. 184 УПК). В отличие от наружного и личного досмотра, личного осмотра, ряда следственных действий, предусмотренных в части 1 ст. 144 УПК, он возможен лишь после возбуждения уголовного дела.

Следует отметить, что личный обыск предусмотрен не только в УПК, но и в законах, регламентирующих содержание под стражей подозреваемых, обвиняемых и осужденных, где является не следственным действием, а режимной мерой.

Так, пункт 2 части 1 ст. 16 Ф3 «О содержании под стражей подозреваемых и обвиняемых в совершении преступлений» [10] предусматривает личный обыск подозреваемых и обвиняемых, а также досмотр их вещей. В части 2 ст. 34 закреплено, что помещения, в которых размещаются подозреваемые и обвиняемые, подвергается обыску, а их вещи, передачи и посылки - досмотру.

В статье 82 Уголовно-исполнительного кодекса РФ [1] закреплено, что осужденные подвергаются обыску, а их вещи - досмотру (ч. 5). Администрация испра- вительного учреждения вправе производить досмотр лиц, находящихся на его территории (ч. 6).

И вновь в приведенном законе и кодексе мы вынуждены констатировать смешение уголовно-процессуальной (обыск) и административной (досмотр) терминологии - теперь уже в другой сфере - содержания под стражей.

Сущностное единство наружного и личного досмотра, личного осмотра и личного обыска при всех правовых различиях проявляется в сходстве технологии (этот термин с легкой руки Р. С. Белкина криминалисты пишут без кавычек) принудительного обследования тела, одежды, личных вещей физического лица [31, С. 150-151; 32, С. 76-77; 33, С. 34-35; 37, C. 342-344].

В. М. Корнуков и Р. Ш. Валиев полагают, что вопрос о возможности использования и доказательственном значении протокола личного досмотра в уголовном деле должен разрешаться судом следующим образом. Если личный досмотр был произведен в ходе предварительной проверки, то протокол должен исключаться как недопустимое доказательство. Если протокол отражает действия по выявлению и оформлению административного либо таможенного правонарушения, которое впоследствии было расценено как преступление, то он может и должен признаваться допустимым доказательством [36].

Соглашаясь в целом с позицией В. М. Корнукова и Р. Ш. Валиева, следует отметить, что личный досмотр зачастую проводится оперативными сотрудниками в рамках оперативно-розыскной деятельности, реализуемой посредством оперативно-розыскных мероприятий (далее по тексту - ОРД, ОРМ).

Тем, кто осуждает сложившуюся практику производства личных досмотров оперативными сотрудниками (как осуществление несвойственных им функций), следует обратиться к ст.ст. 23.3 и 28.3 КоАП, из содержания которых вытекает, что полиция уполномочена рассматривать дела об административных правонарушениях, составлять протоколы и т.д. Любой оперуполномоченный территориального ОВД в соответствии с пунктом 4.1. Приказа МВД России от 5.05. 2012 № 403 является в одном лице субъектом не только оперативно-розыскной, но и административной деятельности.

Эта особенность нашла отражение в криминалистической методике. Так, авторы одного из учебно-методических пособий [40] уделили особое внимание вопросам изъятия наркотиков до возбуждения уголовного дела. Личный досмотр применяется 
оперативными сотрудниками в ходе ОРД, во-первых, в отношении закупщика - чтобы до покупки наркотиков убедиться, что у него их нет. Во-вторых, протоколом личного досмотра оформляется изъятие наркотиков у сбытчика [28].

Сходные рекомендации содержатся в других авторитетных источниках [39].

М. В. Мешков, Е. С. Безруких и В. М. Нечушкин, признавая административную природу личного досмотра, полагают, что когда речь идет об изъятии наркотиков, не зная массы наркотика, всегда можно говорить лишь о возможно совершаемом административном правонарушении. Впоследствии, в случае возбуждения уголовного дела, необходимо принять решение о прекращении производства по делу об административном правонарушении со ссылкой на ряд статей КоАП [40, с. 11]. В учебном уголовном деле приводится образец такого постановления [40, с. 64].

Таким образом, предложен оригинальный выход из проблемной ситуации, учитывая, что дело об административном правонарушении считается возбужденным с момента составления первого протокола досмотра (п. 1 ч. 4 ст. 28.1 КоАП) и поэтому нет необходимости выносить специальное постановление о возбуждении административного производства.

Возможность изъятия наркотических средств путем личного досмотра прямо предусматривает межведомственный подзаконный нормативно-правовой акт [21], в пункте 4 которого записано, что факт изъятия наркотиков из незаконного оборота отражается в протоколе следственного или судебного действия, а при непосредственном обнаружении признаков преступления или наличии других поводов для возбуждения уголовного дела - в протоколе досмотра (основание: ст. 243 КоАП РСФСР, ст. 11 Закона РФ «О милиции», ст. 6 Федерального закона «Об ОРД»), составленном в ходе проведения проверки в порядке ст. 109 УПК РСФСР.

Оставим без подробных комментариев приведенный текст, обратив внимание на то, что, во-первых, остается загадкой, о каком судебном действии идет речь; во-вторых, досмотр якобы предусмотрен оперативно-розыскным и уголовно-процессуальным законодательством; в-третьих, документ подписан руководителями семи федеральных структур и действует до сих пор.

Судебные решения также не отличаются единообразием и четким разграничением разных видов правоохранительной деятельности. Так, Верховный Суд Российской Федерации, отменяя оправдательный приговор Оренбургского областного суда в отношении
Т., отметил в определении, что «признав недопустимыми доказательствами акты личного досмотра С. и Т., при котором сотрудниками ФСБ были обнаружены и изъяты две купюры по 100 долларов США у С. и две купюры по 100 долларов США у Т., суд фактически вошел в противоречие с им же установленными обстоятельствами. Считая, что ст. 74 УПК РФ не предусматривает «акт личного досмотра» как допустимое процессуальное доказательство, суд оставил без оценки факт задержания С. и Т., осуществленного сотрудниками ФСБ в рамках проводимого ими оперативного эксперимента. Их действия в данном случае регламентировались не нормами УПК РФ, а положениями Федерального закона от 12 августа 1995 г. «Об ОРД» [23].

Из приведенного абзаца определения следует, что, во-первых, судьи самого авторитетного звена отечественной судебной системы сочли личный досмотр проявлением оперативно-розыскной, а не административной деятельности. Во-вторых, за рамками определения, то есть без правовой оценки, остался тот факт, что ни в КоАП, ни в Ф3 «О Федеральной службе безопасности» [9] сотрудники службы (кроме пограничников) не были наделены правом на проведение досмотра. Оно закреплено в пункте «и» части 1 ст. 13 указанного Закона лишь в мае 2014 г [16].

Несомненный интерес вызывает оперативно-розыскное законодательство - нет ли в нем возможности принудительного обследования физического лица с изъятием у него чего-либо? Полагаем, что нет, хотя необходимость такого действия с точки зрения теории и практики ОРД очевидна. В части 1 ст. 15 Ф3 «Об ОРД» закреплено право оперативных сотрудников производить при проведении ОРМ изъятие документов, предметов, материалов и сообщений. При этом в случае изъятия составляется протокол в соответствии с требованиями уголовно-процессуального законодательства РФ [14].

Здесь вновь налицо очередное, недопустимое, на наш взгляд, смешение двух разных видов деятельности (оперативно-розыскной и уголовно-процессуальной) и соответствующего законодательства, отождествление ОРМ со следственными действиями. Столь размытые формулировки обоснованно вызвали критику ученых, представляющих разные отрасли права [25, 38]. Действующая редакция части 1 ст. 15 Ф3 «Об ОРД» вызывает много вопросов. Почему изъятие, проведенное в ходе ОРМ, должно оформляться по правилам УПК? Как должен называться протокол? Нужны ли понятые, участие которых в ОРД не только неуместно в силу 
DOI: $10.7256 / 1811-9018.2015 .8 .15966$

При цитировании этой статьи сноска на doi обязательна

\section{Право и политика 8 (188) 2015}

секретного и опасного характера деятельности, но и не предусмотрено законом?

Не менее острой и застарелой в законе, практике и науке уголовного процесса является проблема изъятия в рамках предварительной проверки (ст. 109 УПК РСФСР 1960 г. [26], ст. 144 УПК РФ 2001 г.). Напомним хорошо известный «замкнутый круг»: чтобы возбудить дело о незаконном обороте наркотиков (оружия) надо их предварительно исследовать. Чтобы исследовать - надо изъять, причем желательно у конкретного лица. А вот как изъять что-либо до возбуждения уголовного дела - вопрос, десятилетиями остающийся без ответа. До недавнего времени непреодолимой правовой и практической проблемой являлась сама возможность исследования предметов и документов в ходе предварительной проверки [24].

Вызывает затруднение понимание нового права изымать в ходе предварительной проверки (ч. 1 ст. 144 УПК) предметы и документы «... в порядке, установленном настоящим Кодексом» [41]. Полагаем, что документ должен называться «протокол изъятия» - со ссылкой на процедуры, предусмотренные ст. 183 УПК [29, 30].

На основании изложенного, не претендуя на исчерпывающую полноту, можно по пунктам сформулировать следующие выводы.

1. Адекватное законодательное и научное разграничение сходных с личным обыском правовых понятий (наружный досмотр, личный досмотр, личный осмотр и др.) в настоящее время отсутствует.

2. Множественность указанных понятий, близких по словесным формулировкам и содержанию, но закрепленных в нормативно-правовых актах разных уровней (ведомственные приказы, федеральные законы, кодексы) порождает терминологическую путаницу, негативно влияет на формирование единообразной правоприменительной (административной, оперативно-розыскной, уголовно-процессуальной) практики, дезориентирует должностных лиц правоохранительных органов, серьезно затрудняет доказывание в уголовном судопроизводстве.

3. Представляется целесообразным оставить в федеральном законодательстве два понятия, связанные с принудительным обследованием физического лица (его тела, одежды, личных вещей), - личный досмотр и личный обыск, - применяемые соответственно до и после возбуждения уголовного дела.

4. Аналогичное американскому правило «останови и обыщи» должно быть ясно и четко сформулировано в Ф3 «О полиции» и в других законах, peгулирующих правоохранительную деятельность.

5. Процедура личного досмотра (в кодексах и федеральных законах) и личного обыска (в УПК РФ) должна быть унифицирована - с учетом подробной регламентации указанных действий в более поздних нормативно-правовых актах.

6. Одним из радикальных, но маловероятных решений проблемы является отказ от стадии возбуждения уголовного дела и неразрывно связанной с ней предварительной проверки сообщения о преступлении, то есть наделение следователя, дознавателя правом производства любых следственных действий, включая личный обыск, немедленно после поступления сообщения о преступлении.

7. Более взвешенным представляется предложение разрешить в части 1 ст. 144 УПК РФ проведение личного обыска до возбуждения уголовного дела - в рамках предварительной проверки.

\section{Библиография:}

1. Угловно-исполнительный кодекс Российской Федерации от 08.01.1997 № 1-ФЗ: офиц. текст: по состоянию на 20 апреля 2015 г. // Собрание законодательства Российской Федерации. - 1997. - № 2. - Ст. 198.

2. Воздушный кодекс Российской Федерации от 19.03.1997 № 60-ФЗ: офиц. текст: по состоянию на 18 июля 2015 г. // Собрание законодательства Российской Федерации. - 1997. - № 12. - Ст. 1383.

3. Уголовно-процессуальный кодекс Российской Федерации от 18.12.2001 № 174-ФЗ: офиц. текст: по состоянию на 29 июня 2015 г. // Собрание законодательства Российской Федерации. - 2001. - № 52 (Ч. І). - СТ. 4921.

4. Кодекс Российской Федерации об административных правонарушениях от 30.12.2001 № 195-Ф3: офиц. текст: по состоянию на 11 июля 2015 г. // Собрание законодательства Российской Федерации. - 2002. - № 1 (Ч. I). - Ст. 1.

5. Таможенный кодекс Таможенного союза от 27.11.2009: офиц. текст: по состоянию на 10 октября 2014 г. // Собрание законодательства Российской Федерации. - 2010. - № 50. - Ст. 6615.

6. О чрезвычайном положении: ФКЗ от 30.05.2001 № 3-ФКЗ: офиц. текст: по состоянию на 12 марта 2014 г. // Собрание законодательства Российской Федерации. - 2001. № 23. Ст. 2277.

7. О милиции: Закон Российской Федерации от 18.04.1991 № 1026-1: офиц. текст: по состоянию на 27 июля 2010 г.: утратил силу с 1 марта 2011 г. // Ведомости Съезда народных депутатов и Верховного Совета РСФСР. - 1991. - № 16. - Ст. 503.

8. О Государственной границе Российской Федерации: закон Российской Федерации от 01.04.1993 № 4370-1: офиц. текст: по состоянию на 20 декабря 2006 г. // Рос. газета. - 1993. - 4 мая. 
9. О Федеральной службе безопасности: Ф3 от 03.04.1995 № 40-Ф3: офиц. текст: по состоянию на 22 декабря 2014 г. // Собрание законодательства Российской Федерации. - 1995. - № 15. - Ст. 1269.

10. О содержании под стражей подозреваемых и обвиняемых в совершении преступлений: ФЗ от 15.07.1995 № 103-Ф3: офиц. текст: по состоянию на 22 декабря 2014 г. // Собрание законодательства Российской Федерации. - 1995. - № 29. - Ст. 2759.

11. О наркотических средствах и психотропных веществах. ФЗ от 08.01.1998 № 3-Ф3: офиц. текст: по состоянию на 3 февраля 2015 г. // Собрание законодательства Российской Федерации. - 1998. - № 2. - Ст. 219.

12. О противодействии терроризму: ФЗ от 06.03.2006 № 35-Ф3: офиц. текст: по состоянию на 31 декабря 2014 г. // Собрание законодательства РФ. - 2006. - № 11. - Ст. 1146.

13. О полиции. ФЗ от 07.02.2011 № 3-Ф3: офиц. текст: по состоянию на 6 апреля 2015 г. // Собрание законодательства Российской Федерации. - 2011. - № 7. - Ст. 900.

14. О внесении изменений в отдельные законодательные акты Российской Федерации в части исключения внепроцессуальных прав органов внутренних дел Российской Федерации, касающихся проверок субъектов предпринимательской деятельности: ФЗ от 26.12.2008 № 293-Ф3: офиц. текст: по состоянию на 7 февраля 2011 г. // Собрание законодательства Российской Федерации. - 2008. - № 52 (Ч. 1). - Ст. 6248.

15. О внесении изменений в статьи 62 и 303 Уголовного кодекса Российской Федерации и в Уголовно-процессуальный кодекс Российской Федерации: ФЗ от 04.03.2013 № 23-Ф3: офиц. текст // Российская газета. - 2013. - 6 марта.

16. О внесении изменений в отдельные законодательные акты Российской Федерации: ФЗ от 05.05.2014 № 130-Ф3: офиц. текст // Собрание законодательства Российской Федерации. - 2014. - № 19. - Ст. 2335.

17. О внесении изменений в Кодекс Российской Федерации об административных правонарушениях и отдельные законодательные акты Российской Федерации и о признании утратившими силу отдельных положений законодательных актов Российской Федерации в связи с уточнением полномочий государственных органов и муниципальных органов в части осуществления государственного контроля (надзора) и муниципального контроля: Ф3 от 14.10.2014 № 307-ФЗ: офиц. текст: по состоянию на 13 июля 2015 г. // Собрание законодательства Российской Федерации. - 2014. - № 42. - Ст. 5615.

18. Устав патрульно-постовой службы милиции общественной безопасности Российской Федерации: приказ МВД России от 18.01.1993 № 17: в официальных источниках не опубликован.

19. Устав патрульно-постовой службы полиции: приложение к приказу МВД России от 29.01 .2008 № 80 «Вопросы организации деятельности строевых подразделений патрульно-постовой службы полиции»: офиц. текст: по состоянию на 12 февраля 2015 г. // Бюллетень нормативных актов федеральных органов исполнительной власти. - 2008. - № 27.

20. О полномочиях должностных лиц системы МВД России по составлению протоколов об административных правонарушениях и административному задержанию: приказ МВД России от 05.05.2012 № 403: офиц. текст: по состоянию на 12 января 2015 г. // Бюллетень нормативных актов федеральных органов исполнительной власти. - 2012. - № 36.

21. Инструкция о порядке изъятия из незаконного оборота наркотических средств, психотропных веществ и их прекурсоров, инструментов и оборудования, находящихся под специальным контролем и используемых для производства и изготовления наркотических средств и психотропных веществ, а также их учета, хранения, передачи, использования и уничтожения: приложение к совместному приказу от 09.11.1999 МВД России № 840, Минюста России № 320, Минздрава России № 388, Минэкономразвития России № 472, ГТК России № 726, ФСБ России № 530, ФПС России № 585 // Новая аптека. - 2000. - № 8 .

22. Постановление Конституционного Суда РФ от 02.07.1997 № 11-П по делу о проверке конституционности пункта «б» части 1 ст. 1 Закона Республики Мордовия от 20.01.1996 «О временных чрезвычайных мерах по борьбе с преступностью» в связи с жалобой гр-на Р.К. Хайрова // Собрание законодательства Российской Федерации. - 1997. - № 28. - Ст. 3498.

23. Определение Судебной коллегии по уголовным делам Верховного Суда Российской Федерации от 03.09.2004 № 47-О0475 // Бюллетень Верховного Суда Российской Федерации. - 2005. - № 5. - С. 23-24.

24. Гаврилов, Б. Я. Некоторые вопросы правового регулирования использования специальных знаний при проверке сообщения о преступлении [Текст] / Б. Я. Гаврилов // Криминалистическое учение об организации расследования преступлений: формирование и практическая реализация: матер. межвуз. науч. - практ. семинара «Раскрытие и расследование преступлений: наука, практика, опыт» (г. Москва, 25 марта 2014 г.) / отв. ред. А. Ф. Волынский, Б. Я. Гаврилов, Е. П. Ищенко, И. П. Можаева. - М.: Юрлитинформ, 2014. С. 136-140.

25. Доля, Е. А. Правовое значение результатов гласных оперативно-розыскных мероприятий для уголовного дела и реформы уголовного процесса [Текст] // Законность. 2011. № 4. С. 16-22.

26. Загвоздкин, Н. Н. О проблемах уголовно-процессуального изьятия до возбуждения уголовного дела [Текст] / Н. Н. Загвоздкин // ОВД в борьбе с преступностью на Дальнем Востоке: Сборник научных трудов по материалам межвуз. научно-практ. конф. 18-19 апреля 1997 г. - Хабаровск: Дальневосточный юридический институт МВД России, 1998. С. 173-178.

27. Загвоздкин, Н. Н. Об участии понятых в российском уголовном процессе [Текст] / Н. Н. Загвоздкин // Дальневосточные криминалистические чтения. Вып. 4: Сб. науч. тр. / Отв. ред. В. В. Яровенко. - Владивосток: Изд-во Дальневост. ун-та, 1999. - С. 53-61.

28. Загвоздкин, Н. Н. О некоторых проблемах раскрытия и документирования сбыта наркотических средств [Текст] / Н. Н. Загвоздкин // Актуальные проблемы борьбы с преступностью в Дальневосточном федеральном округе: Сб. матер. Всерос. науч. - практ. конф. 24-25 апреля 2008 г. / Под ред. проф. Е. П. Кима. - Хабаровск: Дальневосточный юрид. ин-т МВД России, 2008. Ч. 2. - С. 444-447. 


\section{Право и политика $8(188) \cdot 2015$}

29. Загвоздкин, Н. Н. О понятых и предварительной проверке сообщения о преступлении [Текст] / Н. Н. Загвоздкин // Проблемы обеспечения законности и правопорядка в Дальневосточном регионе: сб. материалов междунар. науч. - практ. конференции 30-31 мая 2013 г.; ДВЮИ МВД РФ. - Хабаровск: РИО ДВЮИ МВД России, 2013. - С. 253-256.

30. Зажицкий, В. И. Дополнения к статье 144 УПК РФ: плюсы и минусы [Текст] // Рос. юстиция. - 2013. - № 1. - С. 28-31.

31. Зубач, А. В. Основные направления деятельности милиции [Текст]: Учебное пособие / А. В. Зубач, А. Н. Кокорев, Р. А. Русакова. - М.: МосУ МВД России, Изд-во «Щит-М», 2005. - 382 с.

32. Еникеев М. И. Следственные действия: психология, тактика, технология [Текст]: учебное пособие / М. И. Еникеев, В. А. Образцов, В. Е. Аминов. - М.: Проспект, 2011. - 216 с.

33. Калмыков, Г. И. Личный досмотр граждан [Текст]: научно-практическое пособие / Г. И. Калмыков, Н. Ю. Колчевская, А. П. Беликов. - М.: ФГКУ «ВНИИ МВД России», 2013. - 40 с.

34. Ковалевская, Е. По факту убийства полицейского в Грозном возбуждено уголовное дело [Текст] // Российская газета. 2014. - 23 июня.

35. Козлова, Н. Возбуждено уголовное дело по факту убийства сотрудников ДПС [Текст] / Н. Козлова, В. Куликов // Российская газета. - 2014. - 3 ноября.

36. Корнуков, В. М. Личный обыск и его роль в уголовно-процессуальном доказывании / В. М. Корнуков, Р. Ш. Валиев. Саратов, изд-во ГОУ ВПО «Саратовская государственная академия права», 2007. [Электронный ресурс] Доступ из справ. - правовой системы «КонсультантПлюс» (дата обращения: 28.12.2014).

37. Криминалистика [Текст]: Учебник / Н. Г. Шурухнов. - 2-е изд., испр. и доп. - М.: Эксмо, 2008. - 848 с.

38. Макаров, А. В. Проблемы оформления результатов гласных оперативно-розыскных мероприятий [Текст] / А. В. Макаров, О. В. Фирсов // Рос. следователь. - 2013. - № 12. - С. 36-39.

39. Методические рекомендации о проведении проверочных закупок наркотических средств (подготовлены Следственным комитетом при МВД России) [Текст] // Информационный бюллетень Следственного комитета при МВД России. - 2003. - № 1 (115). - С. 78-88.

40. Мешков, М. В. Особенности расследования преступлений в сфере незаконного оборота наркотиков. Учебное уголовное дело [Текст]: Учебно-методическое пособие / М. В. Мешков, Е. С. Безруких, В. М. Нечушкин. - М.: ЦОКР МВД России, 2005. $-228 \mathrm{c}$.

41. Цховребова И. А. Новые процессуальные средства проверки сообщений о преступлениях: что изменилось? [Текст] // Рос. следователь. - 2013. - № 21. - С. 22-24.

\section{References (transliterated):}

1. Gavrilov, B. Ya. Nekotorye voprosy pravovogo regulirovaniya ispol'zovaniya spetsial'nykh znanii pri proverke soobshcheniya o prestuplenii [Tekst] / B. Ya. Gavrilov // Kriminalisticheskoe uchenie ob organizatsii rassledovaniya prestuplenii: formirovanie i prakticheskaya realizatsiya: mater. mezhvuz. nauch. - prakt. seminara «Raskrytie i rassledovanie prestuplenii: nauka, praktika, opyt» (g. Moskva, 25 marta 2014 g.) / otv. red. A. F. Volynskii, B. Ya. Gavrilov, E. P. Ishchenko, I. P. Mozhaeva. - M.: Yurlitinform, 2014. S. 136-140.

2. Dolya, E. A. Pravovoe znachenie rezul'tatov glasnykh operativno-rozysknykh meropriyatii dlya ugolovnogo dela i reformy ugolovnogo protsessa [Tekst] // Zakonnost'. 2011. № 4. S. 16-22.

3. Zagvozdkin, N. N. O problemakh ugolovno-protsessual'nogo iz'”yatiya do vozbuzhdeniya ugolovnogo dela [Tekst] / N. N. Zagvozdkin // OVD v bor'be s prestupnost'yu na Dal'nem Vostoke: Sbornik nauchnykh trudov po materialam mezhvuz. nauchno-prakt. konf. 18-19 aprelya 1997 g. - Khabarovsk: Dal'nevostochnyi yuridicheskii institut MVD Rossii, 1998. S. 173-178.

4. Zagvozdkin, N. N. Ob uchastii ponyatykh v rossiiskom ugolovnom protsesse [Tekst] / N. N. Zagvozdkin // Dal'nevostochnye kriminalisticheskie chteniya. Vyp. 4: Sb. nauch. tr. / Otv. red. V. V. Yarovenko. - Vladivostok: Izd-vo Dal'nevost. un-ta, 1999. - S. 53-61.

5. Zagvozdkin, N. N. O nekotorykh problemakh raskrytiya i dokumentirovaniya sbyta narkoticheskikh sredstv [Tekst] / N. N. Zagvozdkin // Aktual'nye problemy bor'by s prestupnost'yu v Dal'nevostochnom federal'nom okruge: Sb. mater. Vseros. nauch. - prakt. konf. 24-25 aprelya 2008 g. / Pod red. prof. E. P. Kima. - Khabarovsk: Dal'nevostochnyi yurid. in-t MVD Rossii, 2008. Ch. 2. - S. 444-447.

6. Zagvozdkin, N. N. O ponyatykh i predvaritel'noi proverke soobshcheniya o prestuplenii [Tekst] / N. N. Zagvozdkin // Problemy obespecheniya zakonnosti i pravoporyadka v Dal'nevostochnom regione: sb. materialov mezhdunar. nauch. - prakt. konferentsii 30-31 maya 2013 g.; DVYuI MVD RF. - Khabarovsk: RIO DVYuI MVD Rossii, 2013. - S. 253-256.

7. Zazhitskii, V. I. Dopolneniya k stat'e 144 UPK RF: plyusy i minusy [Tekst] // Ros. yustitsiya. - 2013. - № 1. - S. 28-31.

8. Zubach, A. V. Osnovnye napravleniya deyatel'nosti militsii [Tekst]: Uchebnoe posobie/ A. V. Zubach, A. N. Kokorev, R. A. Rusakova. - M.: MosU MVD Rossii, Izd-vo «Shchit-M», 2005. - $382 \mathrm{~s}$.

9. Enikeev M. I. Sledstvennye deistviya: psikhologiya, taktika, tekhnologiya [Tekst]: uchebnoe posobie / M. I. Enikeev, V. A. Obraztsov, V. E. Aminov. - M.: Prospekt, 2011. - 216 s.

10. Kalmykov, G. I. Lichnyi dosmotr grazhdan [Tekst]: nauchno-prakticheskoe posobie / G. I. Kalmykov, N. Yu. Kolchevskaya, A. P. Belikov. - M.: FGKU «VNII MVD Rossii», 2013. - 40 s.

11. Kovalevskaya, E. Po faktu ubiistva politseiskogo v Groznom vozbuzhdeno ugolovnoe delo [Tekst] // Rossiiskaya gazeta. - 2014. -23 iyunya. 
DOI: $10.7256 / 1811-9018.2015 .8 .15966$

При цитировании этой статьи сноска на dоі обязательна

Правоведение

12. Kozlova, N. Vozbuzhdeno ugolovnoe delo po faktu ubiistva sotrudnikov DPS [Tekst] / N. Kozlova, V. Kulikov // Rossiiskaya gazeta. - 2014. - 3 noyabrya.

13. Kornukov, V. M. Lichnyi obysk i ego rol' v ugolovno-protsessual'nom dokazyvanii / V. M. Kornukov, R. Sh. Valiev. - Saratov, izd-vo GOU VPO «Saratovskaya gosudarstvennaya akademiya prava», 2007. [Elektronnyi resurs] Dostup iz sprav. - pravovoi sistemy «Konsul'tantPlyus» (data obrashcheniya: 28.12.2014).

14. Makarov, A. V. Problemy oformleniya rezul'tatov glasnykh operativno-rozysknykh meropriyatii [Tekst] / A. V. Makarov, O. V. Firsov // Ros. sledovatel'. - 2013. - № 12. - S. 36-39.

15. Meshkov, M. V. Osobennosti rassledovaniya prestuplenii v sfere nezakonnogo oborota narkotikov. Uchebnoe ugolovnoe delo [Tekst]: Uchebno-metodicheskoe posobie / M. V. Meshkov, E. S. Bezrukikh, V. M. Nechushkin. - M.: TsOKR MVD Rossii, $2005 .-228$ s.

16. Tskhovrebova I. A. Novye protsessual'nye sredstva proverki soobshchenii o prestupleniyakh: chto izmenilos'? [Tekst] // Ros. sledovatel'. - 2013. - № 21. - S. 22-24. 